\title{
EFFECTS OF CORPORATE GOVERNANCE AND COMPETITION ON CORPORATE PERFORMANCE OF INTERNATIONAL ENTERPRISES
}

\author{
Yaw-Yih WANG \\ Department of International Business, Central Taiwan University of Science and Technology, \\ Taiwan, ROC.E-mail: yywang1954@ctust.edu.tw
}

\begin{abstract}
The occurrence of Asian Financial Crisis and successive scandals highlight the importance of corporate governance on which the public start to stress. "Pursuing internationalization for sustainable development" has become a trend for corporate development in the future. Nonetheless, the promotion of internationalization enhances multiple operating environments and information complexity. An enterprise therefore has to adjust the existing organizational structure and construct favorable corporate governance mechanisms to timely reflect market demands and have the enterprise acquire the advantage of the economy of scale through overseas extension points. With the approach of globalization era, the extreme dependence of economic activities on import/export hastens Taiwan actively joining in World Trade Organization (WTO) to enhance the circulation of goods and resources among member states. Under such a trend, the industrial structure in Taiwan needs to be adjusted, and industries with competitiveness would present larger development space. Aiming at listed companies in Taiwan Stock Exchange, the research period is set 16 years, from 1999 to 2014. The research results conclude that 1 . competition would affect corporate governance, 2. competition would influence corporate performance, and 3. corporate governance would affect corporate performance. The research results are expected to inspire international enterprises with the competition evaluation and corporate governance adjustment to promote the corporate performance.
\end{abstract}

Keywords: international enterprises, corporate governance, competition, corporate performance 


\section{RESEARCH BACKGROUND}

The occurrence of Asian Financial Crisis highlights the importance of corporate governance to be emphasized by the public. The US regulations for corporate governance of enterprises are comparatively complete and strict; however, a lot of scandals being burst out, such as Enron event, Worldcom, Xerox, and Merck $\&$ Co., Inc., result in increasing discussion on the issue of corporate governance. Moreover, a lot of scandals about domestic enterprises' involuntary bankruptcy and asset tunneling also happen in past years, e.g. Procomp, News Singles, and Wong EC, to seriously damage domestic economic systems. As a result, management authorities and investors in various countries present high concerns on corporate governance mechanisms of enterprises in order to ensure the equity not being damaged by enterprises' ill oversight mechanisms or others' manipulation.

Following the trend of internationalization and liberalization in global markets, the increasing economy and trade relationship and dependence among states form a structured global economic system. It therefore greatly impacts existing industrial operating strategies in various countries and hastens most enterprises encountering the choices of industrial upgrading or transformation. Under such a trend, the industrial structure in Taiwan will have to be adjusted, and industries with competitiveness would present larger development space. With the approach of the globalization era, economic activities in Taiwan and enterprises' international strategy placement are often affected by global economic environments. As economic activities in Taiwan extremely depend on import/export, Taiwan actively joins in World Trade Organization (WTO) to enhance the circulation of goods and resources among member states. Fiercely competitive environments would affect corporate performance as the higher competition would reduce managers' behavior of neglect and the waste of corporate resources to further enhance the productivity. When an enterprise enters a brand-new investment market for the global displacement, it would face the unique challenges of customers' consumption patterns and needs, economic systems, and customs and culture in host countries being different from the home country. International enterprises, on the other hand, would invest in large amount of R\&D costs and actively innovate to consolidate existing markets and respond to local market demands, and the internal organizational structure would approach to precise division of labor and professionalization. What is more, the expanding market size would promote the internal and external management complexity and the encountered environmental heterogeneity of the enterprise. In this case, overcoming the liability of foreignness, reducing operational risks, and promoting performance in the internationalization process would become the key success factors in the internationalization of an enterprise. Accordingly, this study is motivated to discuss the 
relationship among international enterprises' corporate governance, competition, and operating performance. It is expected that the research results would inspire international enterprises in the competition evaluation and corporate governance adjustment to promote the corporate performance.

\section{LITERATURE REVIEW AND HYPOTHESIS}

\subsection{Corporate governance}

Banerjee and Bonnefous (2011) explained corporate governance mechanism as to ensure investors, the capital providers, acquiring the deserved rewards. Brealey et al. (2011) defined corporate governance as a mechanism to supervise an enterprise practicing internal and external auditing in order to ensure the enterprise conforming to social norms, proceeding relevant operating activities, and considering stakeholders' benefits. Cheng et al. (2011) pointed out corporate governance mechanism as the norms or principles established by an enterprise, definitely defining the work responsibilities and the responsibilities for external investors, to supervise the behaviors of corporate owners, directors, and managers (e.g. stockholders). According to corporate governance mechanism, Collins and Morten (2011) extended the meaning as enhancing strategic management effectiveness and supervising managers' behaviors through system design and execution so as to ensure the deserved rewards of external investors (minority stockholders and creditors) and give considerations to other stakeholders' benefits. More specifically, corporate governance mechanism was to prevent deputies damaging corporate value and reinforce corporate competitiveness and management effectiveness in order to guarantee the equity of capital providers and other stakeholders (Črnigoj and Mramor 2015). Dhaliwal et al. (2011) regarded it as the contract between stockholders internally defined by a company and management echelon in charge of the management; the core of internal corporate governance mechanism was the board of directors, who were responsible for the sustainable management of the company and supervising administrative authorities who were responsible for the management. When financial crises occurred in the company, the board of directors was also responsible for the creditors. Apparently, the board of directors was responsible for both stockholders and the company. Elamin and Tlaiss (2015) regarded the close relationship between corporate governance and ownership diversification. When stock rights were extremely dispersed, the management echelon was mostly undertaken by professional managers; and, corporate governance focused on designing a system to prevent such professional 
managers considering their own benefits, even pocketing with their authorities and neglecting other stockholders' equity.

Hall and Wagner (2012) considered that a company was composed of stockholders, employees, creditors, managers, consumers, suppliers, governmental organizations, and financial institutions and a contract relying on the common goods was provided for such stakeholders in order to correct and restrain the behaviors. In short, agency theory aimed to discuss the occurrence of distinct agent relationship and the management mechanism. Nevertheless, Kao et al. (2012) indicated that, after an enterprise separating ownership and management rights, managers took charge of most operation and management affairs of the company, but the wealth was not obviously related to corporate performance because of fewer stocks held. In this case, managers might hide important information and engage in illegal and self-interested behaviors with the authorities when their goals conflicted with corporate objectives and the managers possessed more information than the owner did. Michelon and Parbonetti (2012) indicated that the corporate governance mechanism of an enterprise would change with the internationalization as the complexity of information handled by managers was enhanced and the required professional competence and knowledge became multiple to effectively make decisions beneficial to the enterprise, when the degree of internationalization was enhanced. Referring to Michelon and Parbonetti (2012), the following indicators are contained in this study for corporate governance:

(1) CEO salary = sum of CEO rewards, bonuses, special disbursement, stocks, and cash dividends,

(2) $\mathrm{CEO}$ shareholding ratio $=\mathrm{CEO}$ number of shares held $/$ number of shares outstanding,

(3) Independent director ratio $=$ number of independent directors and supervisors / sum of the board of directors.

\subsection{Competition}

Al-Shboul and Anwar (2014) pointed out competition as the degree of a company's external competition. Industrial concentration ratio was normally used for measuring industrial competition. The so-called industrial concentration ratio referred to the ratio of the sales volume of several largest businesses to all sales volume in the industry or describing the size and number of businesses in the industry. The number of businesses and the size difference were the key factors in the industrial monopoly. The more number of businesses and the fewer differences in sizes presented the lower industrial concentration ratio that the market was closer to a pure competition market. Based on market concentration ratio, Cai et al. (2012) classi- 
fied market competition into pure monopoly, monopoly dominant firm, tight oligopoly, loose oligopoly, monopolistic competition, and pure competition. Chien (2013) proposed to test market structure with unstructured analysis, and the model was constructed under the following assumptions. (1) The market was balanced. (2) Businesses pursued profit maximization or cost minimization. Applying the ideas to this study, monopoly market, monopolistic competition market, and pure competition market are explained as below.

(1) Monopoly market: Monopoly proposed by Michelon and Parbonetti (2012) does not mean merely one business in the market, but refers to the price decision not being influenced by other strategic interaction or threats.

(2) Monopolistic competition market: Other competitors are considered in the decisions of monopolistic competitive businesses; the more businesses in the market, the higher substitution level of businesses to decrease individual business's needs.

(3) Pure competition market: In pure competition markets, businesses could freely enter the market and acquire production techniques for free.

\subsection{Corporate performance}

Performance, as a direct outcome, is the measurement of an organization achieving the objective (Bartram and Bodnar 2012). In other words, performance is 1. benefits and effectiveness to complete tasks, 2 . evaluated working behaviors, methods, and results, and 3. working results of employees presenting effectiveness and contribution to an enterprise achieving the objectives. Performance, as the combination of results and effectiveness, is an enterprise achieving the benefits and objectives as well as the effectiveness and outcomes in a period of time. To quantify the operation of a company, the comparison of the operation being cost effective, and the commercial benefits is regarded as performance measurement, which could be divided into financial performance, business performance, and business efficiency, where sales growth, profitability, earnings per share (EPS), and Tobin's Q are often utilized for reflecting the true economic situations of a company (Chava 2011). Performance is the key indicator to measure corporate operation, while operating performance could directly affect the survival of an enterprise. The success of policies or objectives of an enterprise could be judged the effectiveness through the measurement of performance (Chung and Zhou 2012). The measurement of organizational performance could be divided into subjective performance and objective performance. Subjective performance presents managers' satisfaction with the overall operation, such as members' satisfaction, expected return, trust of organizational members, management 
ability, and sustainability of organization (De Haan and Sterken 2011). Objective performance is the financial data of an organization, e.g. sales growth rate and market share, return on assets (ROA), and return on stockholders' equity (ROE) (El Ghoul et al. 2011). Objective performance, i.e. organizational financial performance, is utilized for measuring corporate performance in this study; return on assets or return on stockholders' equity being used as the variable to measure corporate performance might result in return on assets or return on stockholders' equity not being able to completely represent corporate performance because of the difference in accounting (Goss and Roberts 2011). A lot of research therefore suggests to measure corporate performance with Tobin's $\mathrm{Q}$ ratio (dividing market value by the replacement price of tangible assets) and P/B-price-book. Tobin's $\mathrm{Q}$ ratio and $\mathrm{P} / \mathrm{B}$-price-book therefore are used for measuring corporate performance in this study.

Tobin's $\mathrm{Q}$ is the ratio of the market value of a company's assets to the replacement value in the capital market. Corporate value contains the value of existing assets and the value of growth opportunity. The former refers to the sum of present discounted value of a company's existing assets being able to generate cash flow without new investment, and the latter is determined by the amount invested in the future and the difference between return on investment and required rate of return (Hardi and Buti 2012). Tobin's Q used to be regarded as the proxy variable in past research to measure corporate value and operating performance. The higher Tobin's Q could represent the larger intangible assets or growth opportunity created by a company (Kuo et al. 2012). In addition to the fixed assets, the value of intangible assets, such as reputation, patent, market oligopoly, or operating ability, of a company could be used for measuring Tobin's Q and reflecting the growth opportunity. Tobin's $Q$ therefore stands for a company predicting the future market value and performance (Nick and Igor 2011). EPS is the profitability of each share, i.e. the profit of a company in a certain period being divided by the number of circulated shares; earnings per share are generally used. It is measured by EPS $=$ surplus in preceding fiscal year-preference dividend/number of circulated shares. Preferred stock is included in stocks, but a part of the properties is similar to bonds; the house of issue would provide dividends for preferred stockholders, and the received dividends are similar to the interest income of bondholders.

\subsection{Effects of competition on corporate governance}

Grimminger and Benedetta (2013) indicated that competition could merely be increased by reducing managers' behavior of neglect. Jo and Harjoto (2012) also agreed that a company in the pure competition market would reduce the man- 
agers' behavior of neglect as the company without pursuing profit maximization would be eliminated by the market mechanism. Leventis and Dimitropoulos (2012) considered that a company in the industry with lower product competition would be hard to operate the oversight mechanism in the product market. The idea supported the viewpoint of Noronha et al. (2013) that market competition, as an important disciplinary mechanism, could reduce managers' neglect. Oikonomou et al. (2012) pointed out the mutual reinforcement effect, rather than substitution effect, between strong product market competition and good governance mechanisms. Furthermore, Samia et al. (2011) found out the negative relationship between corporate governance and industrial concentration ratio, presenting the casual relationship between corporate governance and competition. They further discovered that an enterprise with weaker competition in the industry would provide less protection for the investors, i.e. the worse corporate governance mechanism. The following hypothesis is therefore proposed in this study.

H1: Competition would affect corporate governance.

\subsection{Effects of competition on corporate performance}

Soti and Gupta (2013) found out the positive correlation between competition and corporate productivity, showing the higher competition, the fewer managers' behavior of neglect and the lower waste of corporate resources to further enhance the productivity. They also indicated that product market competition is a factor in stimulating business efficiency. Chung and Zhou (2012) also pointed out the significantly positive correlation between competition and a company's profitability and productivity. In the research on the effects of product market competition and ownership structure on corporate performance, De Haan and Sterken (2011) found out the remarkably positive correlation between product market competition and corporate performance. Goss and Roberts (2011) also pointed out the positive effects of product market competition on corporate performance. The following hypothesis is therefore proposed in this study.

$\mathrm{H} 2$ : Competition would affect corporate performance.

\subsection{Effects of corporate governance on corporate performance}

Brealey et al. (2011) mentioned that competition in both product market and capital market could become corporate governance mechanisms; therefore, favorable corporate governance mechanisms should integrate internal investors like the board of directors and external product market competition. Product market 
competition could bring distribution efficiency and corporate governance mechanisms could generate efficiency; both would affect corporate performance. Elamin and Tlaiss (2015) assumed that enterprises with ownership diversification had the managers control the management right. In this case, managers, without high shareholding ratio, would not undertake the failure that the so-called agent problem could easily occur. Kao et al. (2012) considered that when an enterprise separated ownership and management rights, managers might pursue the maximization of personal effectiveness based on selfish motivation and disobey corporate profits as they need not undertake extra risks. As a result, increasing the shareholding of managers could balance the personal profit with other stockholders to enhance the value of the company. Cai et al. (2012) mentioned that independent directors, not being insiders of a company, would comparatively not encroach on stockholders' equity and be more objective to maintain independent operation than internal directors who might utilize excellent information for colluding with managers. Chien (2013) indicated that independent directors could enhance the efficiency of the board of directors and could better guarantee general stockholders' equity than internal directors did. Michelon and Parbonetti (2012) also discovered that the stock price would notably rise once the news of an independent director being designated was announced. The following hypotheses therefore are proposed in this study.

H3: Corporate governance would affect corporate performance.

H4: Competition has moderating effects on the effects of corporate governance on corporate performance.

\section{RESEARCH STRUCTURE AND SUBJECT}

\subsection{Research structure}

Summing up the above literatures, the conceptual structure (Figure 1) is drawn in this study to discuss the relationship among competition, corporate governance, and corporate performance.

\subsection{Research subject and sampling data}

Taking listed companies in Taiwan Stock Exchange as the research samples where unsuitable industries are removed, total 10 industries are included in this study. As the acquisition of domestic internationalization data is limited and the database is updated to 2014, merely the period in 2010-2014 is studied. 


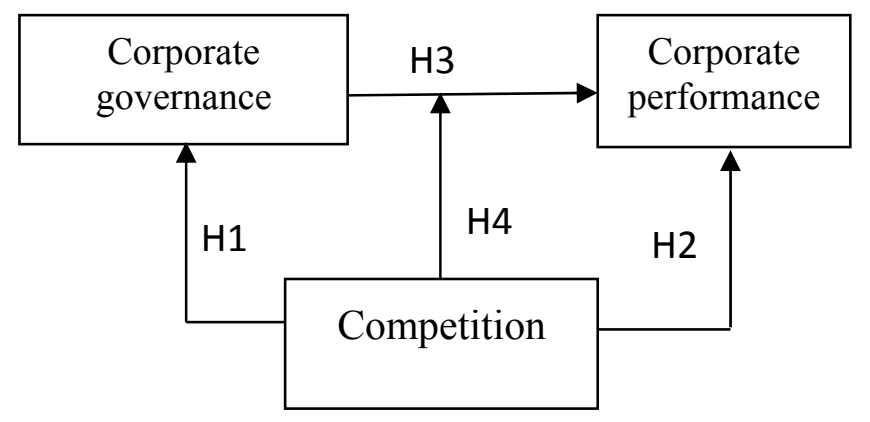

Figure 1. Research structure

\subsection{Analysis method}

Analysis of Variance is utilized for discussing the difference of competition in corporate governance and corporate performance as well as understanding the effects of corporate governance on corporate performance.

\section{ANALYSIS RESULT}

\subsection{Effects of competition on corporate governance and corporate performance}

\subsubsection{Variance analysis of competition in corporate governance}

Applying Analysis of Variance to discuss the difference of competition in corporate governance, competition aiming at monopoly market, monopolistic competition market, and pure competition market are analyzed and explained. From Table 1, competition presents notable difference on corporate governance that $\mathrm{H} 1$ is supported.

Table 1. Variance analysis of competition in corporate governance

\begin{tabular}{l|c|c|c}
\hline Variable & $\mathrm{F}$ & $\mathrm{P}$ & Scheffe post hoc \\
\hline CEO salary & 16.337 & $0.006^{*}$ & $1>23$ \\
\hline CEO shareholding ratio & 12.531 & $0.000^{*}$ & $1>2>3$ \\
\hline Independent directors ratio & 8.776 & $0.012^{*}$ & $1>23$ \\
\hline
\end{tabular}

* stands for $\mathrm{p}<0.05$ 


\subsubsection{Difference analysis of competition in corporate performance}

Utilizing Analysis of Variance for discussing the difference of competition in corporate performance, competition aiming at monopoly market, monopolistic competition market, and pure competition market are analyzed and explained. From Table 2, competition reveals significant difference on corporate performance that $\mathrm{H} 2$ is supported.

Table 2. Variance analysis of competition on corporate performance

\begin{tabular}{l|c|c|c}
\hline Variable & F & P & Scheffe post hoc \\
\hline Tobin's Q & 14.252 & $0.021^{*}$ & $1>23$ \\
\hline P/B-price-book & 23.486 & $0.000^{*}$ & $1>2>3$ \\
\hline
\end{tabular}

* stands for $\mathrm{p}<0.05$

\subsection{Difference analysis of corporate governance in corporate performance}

Applying Analysis of Variance to discuss the difference of corporate governance in corporate performance, corporate governance aiming at CEO salary, CEO shareholding ratio, and independent director ratio are analyzed and explained. From Table 3, CEO salary, CEO shareholding ratio, and independent director ratio present remarkable difference on corporate performance that $\mathrm{H} 3$ is supported.

Table 3. Variance analysis of corporate governance on corporate performance

\begin{tabular}{l|c|c|c}
\hline Variable & F & P & Scheffe post hoc \\
\hline Tobin's Q & 10.915 & $0.003^{*}$ & $12>3$ \\
\hline P/B-price-book & 18.274 & $0.000^{*}$ & $12>3$ \\
\hline
\end{tabular}

* stands for $\mathrm{p}<0.05$

Data source: Self-organized in this study.

\subsection{Effect analysis of competition on corporate governance and corporate performance}

According to Analysis of Variance discussing the difference of competition and corporate governance in corporate performance, the interaction between competition and corporate governance is explored to test the effect of competition. From the interaction in Table 4, CEO salary presents the highest competition in monopoly market on Tobin's $\mathrm{Q}$ and in monopolistic competition market on 
P/B-price-book, Figure 2. The margin mean in Figure 3 apparently shows the significant interaction that $\mathrm{H} 3$ and $\mathrm{H} 4$ are supported.

Table 4. Effects of competition and corporate governance on corporate performance

\begin{tabular}{l|c|c|c|c|c|c}
\hline Variable & \multicolumn{3}{|c|}{ Tobin's Q } & \multicolumn{3}{c}{ P/B-price-book } \\
\hline & $\mathrm{F}$ & $\mathrm{P}$ & Scheffe post hoc & $\mathrm{F}$ & $\mathrm{P}$ & Scheffe post hoc \\
\hline $\begin{array}{l}\text { Corporate gover- } \\
\text { nance }\end{array}$ & 10.915 & $0.003^{*}$ & $12>3$ & 18.274 & $0.000^{*}$ & $12>3$ \\
\hline Competition & 14.252 & $0.021^{*}$ & $1>23$ & 23.486 & $0.000^{*}$ & $1>2>3$ \\
\hline $\begin{array}{l}\text { Corporate gover- } \\
\text { nance* competi- } \\
\text { tion }\end{array}$ & 27.633 & $0.000^{* *}$ & $\begin{array}{c}11>12>13> \\
21>22>23> \\
33>32>31\end{array}$ & 24.514 & $0.000^{* *}$ & $\begin{array}{c}22>23>21> \\
33>32>31\end{array}$ \\
\hline
\end{tabular}

$*$ stands for $\mathrm{p}<0.05, * *$ for $\mathrm{p}<0.01$

\section{Tobin's Q}

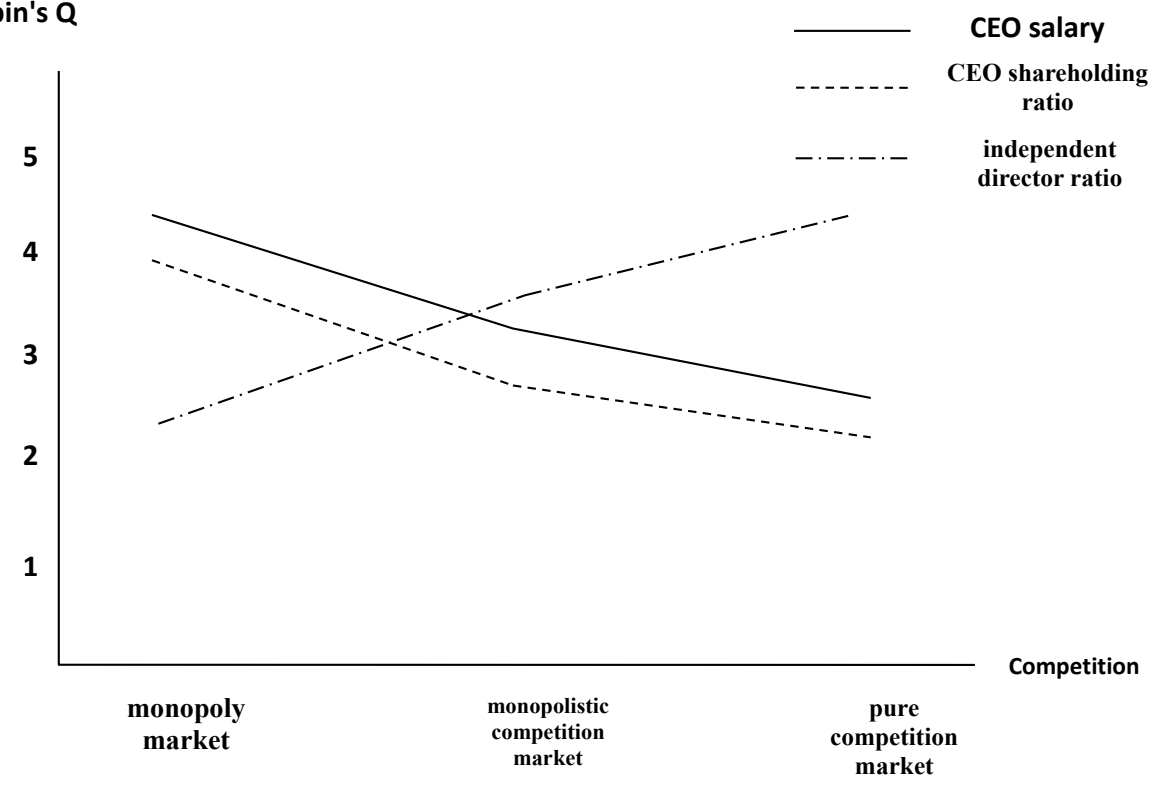

Figure 2. Margin mean 


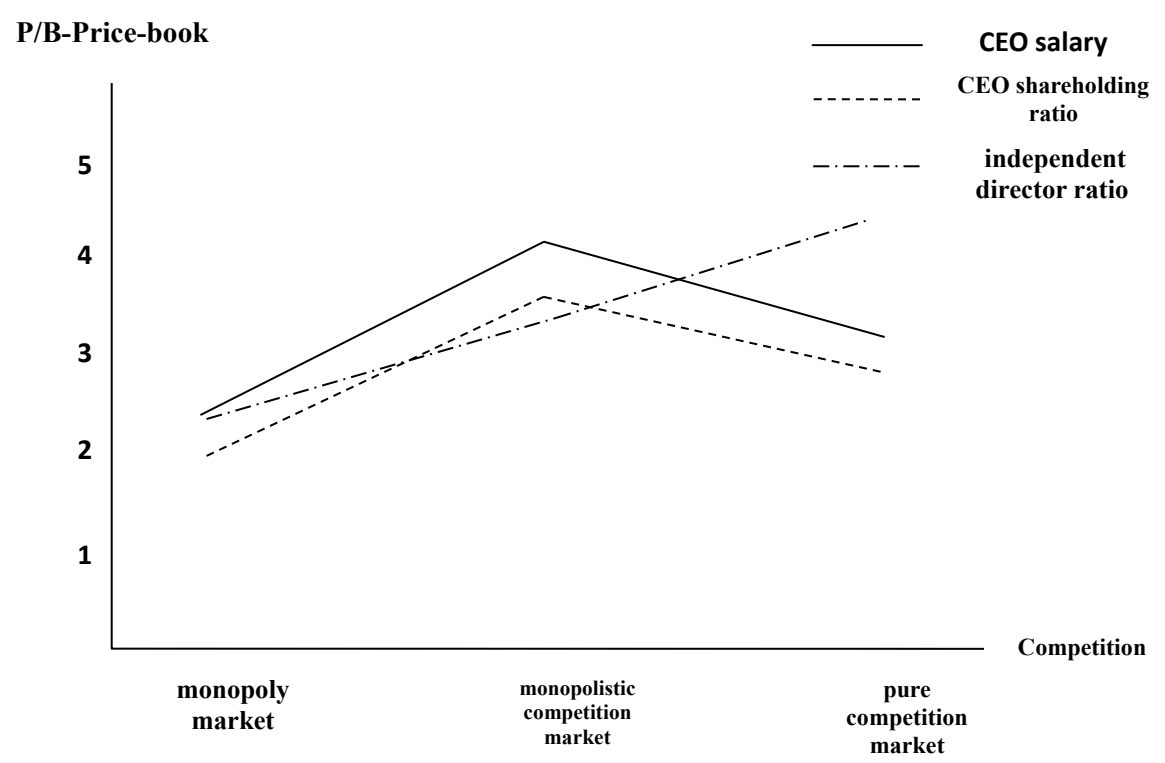

Figure 3. Margin mean

\section{CONCLUSION}

The empirical results show that the higher competition of businesses in Taiwan, the lower salary for managers and placement of independent directors. However, managers' salaries and the placement of independent directors are closely related to the operating performance that it is inferred that the internationalization of domestic businesses still remains at the initial stage. The inadequate operating experiences in internationalization markets could not instantaneously respond to different operating environments from home country (such as designing a reasonable reward system to cope with overseas additional pay, allowance for living expenses, and tax subsidy in local environment). In this case, the higher competition for corporate internationalization results in the lower CEO salary. Besides, another possibility is that domestic enterprises tend to reward managers with stock rights and salary. Such a tactic originally intends to encourage managers with variable salaries, but it ignores the abundant expenses in the beginning of internationalization causing the operating performance not being able to reflect the stock price so that the predicted encouragement is reduced. The notable effect of corporate governance on corporate performance conforms to Michelon and Parbonetti's (2012) research result of positive correlations between stock rewards and corporate governance. In other words, better corporate governance would enhance 
stock rewards; and the effect of corporate governance on corporate performance is apparent. Investors therefore should pay attention to the quality of corporate governance and consider the internationalization and competition to construct the investment combination. For a company, it is necessary to reinforce corporate governance in any competitive environments. When an enterprise presents high competition and proceeds high internationalization, such as establishing overseas branches and overseas common investment, the enterprise presents favorable corporate governance mechanisms to make larger profits.

\section{SUGGESTION}

Aiming at the above research results, the following suggestions are proposed in this study.

1. Governments in various states have positively implemented transformation and innovation to industries in past years. Under such a trend, the exclusive market and resources might approach to saturation. In this case, establishing an exclusive brand and searching for opportunities to step out the market have become essential for businesses in Taiwan. Nonetheless, businesses would encounter the threats of existing industrial manpower, resources, and experience transfer in the process as well as various potential factors in operating performance in new investment environments (e.g. local consumption habits, political and economic policies, and exchange rate fluctuation). Such problems might be the key success factors in international businesses' corporate governance and corporate performance. Accordingly, corporate governance is not the sole factor in corporate performance.

2. An enterprise could re-examine the internal salary and director structure in order to make the up-to-date and adaptable policy for retaining and recruiting talents with good performance, to encourage existing managers to develop the strength for the enterprise, and to attract talents so as to develop and expand multiple, deep, and broad operation thinking model for the organization.

3. Based on the research results and the uniqueness of stock right structure in Taiwan, enterprises are suggested to establish complete protection policies for minority stockholders and to correspond to the importance of corporate governance quality promoted by the public and enterprises. What is more, enterprises should try to strengthen domestic industrial competition in order to reinforce the competitiveness. After all, Taiwan is an island; internationalization is a trend for enterprises. An enterprise could make higher profits by keeping the competitive advantages, maintaining the competitiveness, and proceeding internationalization. 


\section{REFERENCES}

Al-Shboul, M. and Anwar, S. (2014). Foreign exchange rate exposure: Evidence from Canada. Review of Financial Economics, 23, 18-29.

Banerjee, B. and Bonnefous, A. (2011). Stakeholder management and sustainability strategies in the French nuclear industry. Business Strategy and Environment, 20(2), 124-140.

Bartram, S.M. and Bodnar, G.M. (2012). Crossing the lines: The conditional relation between exchange rate exposure and stock return in emerging and developed markets. Journal of International Money and Finance, 31(4), 766-792.

Brealey, A.R., Myers, C.S. and Allen, F. (2011). Principles of Corporate Finance, 10th edition. New York: McGraw-Hill/Irwin.

Cai, Y., Jo, H. and Pan, C. (2012). Doing well while doing bad? CSR in controversial industry sectors. Journal of Business Ethics, 108(4), 467-480.

Chava, S. (2011). Environmental Externalities and Cost of Capital. Working paper. Georgia Institute of Technology.

Cheng, B., Ioannou, I. and Serafeim, G. (2011). Corporate Social Responsibility and Access to Finance. Working paper. Harvard University.

Chien, Y.C. (2013). The effects of organizational performance on the intellectual capital accumulation of Taiwan-listed biotechnology companies: Organizational citizen behavior as a moderator. The Journal of Human Resource and Adult Learning, 9(1), 40-54.

Chung, Y.P. and Zhou, Z.G. (2012). The pricing of exchange rate risk in the stock market: A nonparametric approach. Studies in Nonlinear Dynamics and Econometrics, 16(1), 1-33.

Collins, J. and Morten, T. H. (2011). Great by Choice. Published by arrangement with Curtis Brown Ltd.

Črnigoj, M. and Mramor, D. (2015). Alternative corporate governance paradigm and corporate financing: Capital structure decisions in employee-governed firms. Acta Oeconomica, 65(2), 271-297.

De Haan, L. and Sterken, E. (2011). Bank-specific daily interest rate adjustment in the Dutch mortgage market. Journal of Financial Services Research, 39, 145-159.

Dhaliwal, D., Li, O., Tsang, A. and Yang, Y. (2011). Voluntary nonfinancial disclosure and the cost of equity capital: The initiations of corporate social responsibility reporting. Accounting Review, 86(1), 59-100.

El Ghoul, S., Guedhami, O., Kwok, C.C.Y. and Mishra, D.R. (2011). Does corporate social responsibility affect the cost of capital. Journal of Banking \& Finance, 35(9), 2388-2406.

Elamin, A.M. and Tlaiss, H.A. (2015). Exploring the relationship between organizational citizenship behavior and organizational justice in the Islamic Saudi Arabian context. Employee Relations, 37(1), 29-47.

Goss, A. and Roberts, G.S. (2011). The impact of corporate social responsibility on the cost of bank loan. Journal of Banking \& Finance, 35(7), 1794-1810.

Grimminger, A.D. and Benedetta, P.D. (2013). Raising the Bar on Corporate Governance: A Study of Eight Stock Exchange Indices. Washington DC: The World Bank.

Hall, J. and Wagner, M. (2012). "Integrating sustainability into firms" processes: performance effects and the moderating role of business models and innovation. Business Strategy and the Environment, 21(3), 183-196.

Hardi, P. and Buti, K. (2012). Corporate governance variables: Lessons from a holistic approach to Central-Eastern European practice. Corporate Governance, 12(1), 101-117.

Jo, H. and Harjoto, M. (2012). The causal effect of corporate governance on corporate social responsibility. Journal of Business Ethics, 106(1), 53-72. 
Kao, L.F., Lu, C.S., Huang, K.C. and Chen, A.L. (2012). Corporate governance, firm performance, and investment strategy. Sun Yat-Sen Management Review, 20(3), 851-880.

Kuo, L., Yeh, C.C. and Yu, H.C. (2012). Disclosure of corporate social responsibility and environmental management: Evidence from China. Corporate Social Responsibility and Environmental Management, 19(5), 273-287.

Leventis, S. and Dimitropoulos, P. (2012). The role of corporate governance in earnings management: Experience from US banks. Journal of Applied Accounting Research, 13(2), 161-177.

Michelon, G. and Parbonetti, A. (2012). The effect of corporate governance on sustainability disclosure. Journal of Management \& Governance, 16(3), 477-509.

Nick, L.H. and Igor, B. (2011). The relationship between corporate governance, global governance, and sustainable profits: Lessons learned from BP. Corporate Governance, 11(5), 571-584.

Noronha, C., Tou, S., Cynthia, M.I. and Guan, J.J. (2013). Corporate social responsibility reporting in China: An overview and comparison with major trends. Corporate Social Responsibility and Environmental Management, 20(1), 29-42.

Oikonomou, I., Brooks, C. and Pavelin, S. (2012). The impact of corporate social performance on financial risk and utility: A longitudinal analysis. Financial Management, 41(2), 483-515.

Samia, H., Wangb, J. and Zhou, H. (2011). Corporate governance and operating performance of Chinese listed firms. Journal of International Accounting, Auditing and Taxation, 20(2), 106-114.

Soti, P. and Gupta, S. (2013). Impact of corporate governance on the financial performance of Indian IT companies listed on Stock Exchange. International Journal of Management Research and Reviews, 3(3), 2635-2647. 